\title{
JUDICIAL PREFERENCES, PUBLIC CHOICE, AND THE RULES OF PROCEDURE
}

\author{
JONATHAN R. MACEY*
}

\section{INTRODUCTION}

$\mathbf{R}$

ULEs of procedure determine and reflect the transaction costs of operating a legal system. An efficient procedural system is one that minimizes the sum of the costs of erroneous judicial decisions and the costs of operating the system. ${ }^{1}$ However, the rules of procedure are formulated by judges. If the self-interest of those judges conflicts with the efficiency criterion, it would seem plausible that the judges will formulate procedural rules that further their own interests rather than the interests of efficiency. ${ }^{2}$

The prediction that judicial behavior is likely to conform to judges' rational self-interest rather than to the interest of economic efficiency appears to be particularly valid in the context of a discussion about procedural rules. Such rules are not only construed by judges, they also are promulgated under the direction of judges. ${ }^{3}$ The Advisory Committee on

* J. DuPratt White Professor of Law, Cornell University. I am extremely grateful for the valuable comments I received from Kevin Clermont. The help he provided for this article far exceeded the usual requirements of colleagueship. I also am very grateful for the useful comments I received from Lewis Kornhauser, Geoffrey Miller, and Thomas Rowe. Presented at the John M. Olin Program in Law and Economics Conference on "Economic Analysis of Civil Procedure" at the University of Virginia School of Law, March 26-27, 1993.

1 Richard A. Posner, Economic Analysis of Law 549 (4th ed. 1992).

${ }^{2}$ See, for example, Mark A. Cohen, Explaining Judicial Behavior, or What's "Unconstitutional" about the Sentencing Commission, 7 J. L. Econ. Org. 183, 184 (1991).

${ }^{3}$ Congress delegated rule making in the area of civil procedure to the Supreme Court in the Rules Enabling Act of 1934, 28 U.S.C. \$ 2072 (1982). In 1958 Congress provided that the Judicial Conference of the United States should monitor the rules of civil procedure and recommend changes to the Supreme Court. The Judicial Conference established a Standing Committee on Rules of Practice and Procedure and an Advisory Committee on Practice and Procedure in Civil Cases. See Annual Report of the Proceedings of the Judicial Conference of the United States 6-7 (1958).

[Journal of Legal Studies, vol. XXIII (January 1994)]

(C) 1994 by The University of Chicago. All rights reserved. 0047-2530/94/2301-0026\$01.50 
Practice and Procedure in Civil Cases, which initiates revision of the Federal Rules of Civil Procedure, is composed primarily of judges, with a sprinkling of practicing lawyers and academics. The present membership of the Advisory Committee on Civil Rules includes two circuit judges, four district judges, one U.S. magistrate, one state court judge, a representative of the U.S. Department of Justice, two private lawyers, and two law professors. ${ }^{4}$ The rules of procedure promulgated by this advisory committee must be approved in final form by the Supreme Court, after first being filtered through the Standing Committee on Rules of Practice and Procedure and the Judicial Conference of the United States. To date, however, the Supreme Court has served as a mere conduit for the work of the advisory committee, approving the vast majority of changes recommended to it by the committee.

Judicial rule making is not completely independent of legislative control because amendments are subject to congressional oversight. But Congress typically acquiesces in the promulgation of civil rules amendments. Because procedural rules are designed to facilitate judicial administration, judges are given considerable leeway to craft such rules to conform to their preferences.

Regardless of the motivations of the judges involved in crafting the rules of procedure, it seems beyond dispute that the lawyers involved in this process will have little to gain from minimizing the costs of the procedural system. As Judge Ralph Winter has observed, "[I]mportant segments of the organized bar have little incentive to lessen the cost of litigation by reducing the need for unnecessary legal services. Those who seek to reform the [procedural rules of] discovery are unlikely ever to find their proposals commanding enthusiastic support among the organized Bar.",5

It is surprising that the existing economic literature on the rules of procedure uniformly has ignored the possibility of self-interest and instead has presumed that judges exercise their considerable discretion to formulate procedural rules that promote the goals of economic efficiency. The lack of attention to self-interest is particularly surprising in light of the fact that studies of particular procedural rules from an economic perspective generally show that the rules do not produce results consistent with economic efficiency. ${ }^{6}$

\footnotetext{
${ }^{4}$ Randall Samborn, Committee Who's Who, Nat'l L. J., May 4, 1992, at 12.

${ }^{5}$ Ralph K. Winter, In Defense of Discovery Reform, 58 Brooklyn L. Rev. 263, 277 (1992).

${ }^{6}$ Id. (arguing that existing pretrial discovery rules are inefficient); Geoffrey P. Miller, An Economic Analysis of Rule 68, $15 \mathrm{~J}$. Legal Stud. 93 (1986) (concluding that the rule is ineffective in achieving its intended result of encouraging settlements and suggesting a more efficient rule).
} 
Starting with the assumption that judges seek to maximize self-interest, this article represents a preliminary attempt to develop a framework that will generate useful predictions about the likely contours of procedural rules. The article then compares the predictions generated by its model of self-interested judicial behavior with existing procedural rules. While the self-interest model developed here is not sufficiently well specified to generate quantitative results that yield the possibility of rigorous empirical refutation, the competing public interest model is equally undeveloped. Useful comparisons between the existing approach model and the public choice approach developed here, however, still can be made by comparing qualitative descriptions of the effects of existing rules with the predictions generated by these rival approaches. ${ }^{7}$

Having staked out a bold claim about the usefulness of the methodology developed in this article, qualifications are in order. First, over a wide range of issues, the self-interest model and the public interest model of procedural rules will generate similar outcomes. It is only where the self-interest of judges conflicts with the public interest in efficient judicial administration that the differences between the two theories become important. Moreover, as developed more fully below, in certain contexts, the two theories will converge because judges have an interest in efficient administration. But, because judges do not fully internalize either the costs of their own errors or the costs of an inefficient administration of justice, judges' self-interest will conflict with efficiency values. It is where such conflict exists that a theory of procedure built on judicial self-interest has value.

Second, the theory of judicial self-interest discussed here does not conflict with the theory that substantive common-law rules tend to be more efficient than statutes or administrative law rules. Indeed, as will be seen, the same self-interest that shapes procedural rules to reflect judicial preferences also causes judges to generate efficient common-law rules. In particular, judges can reduce their caseloads and eliminate duplicative efforts by crafting clear rules where they are able. This, of course, contributes to efficiency. Moreover, a judge can enhance his or her prestige within the judiciary by fashioning creative, workable solutions to existing legal problems. This too contributes to the efficiency of the legal system.

This article begins with a general description of the likely preference functions of judges and considers how these preferences might influence the content of procedural rules. These observations are then compared with existing procedural rules. It seems that such rules are best explained with reference to judicial self-interest.

\footnotetext{
${ }^{7}$ Posner, supra note 1 , at 550.
} 


\section{Bureaucratic Preferences: The Nature of Judicial Self-Interest}

Any viable theory of judicial self-interest must account for the structural characteristics of the federal judiciary. Individual judges will have widely varying preferences. Some will want to maximize leisure, some will want to maximize their own prestige among some subgroup such as lawyers, legal academics, or liberal or conservative groups. The same is true of the individual members of Congress. Each group is composed of individuals with widely varying preferences. ${ }^{8}$ What is generally ignored, however, is that, like Congress, the judiciary is a bureaucracy with its own set of institutional preferences. The rules of civil procedure are designed to further this set of bureaucratic preferences.

The nature of the judiciary's bureaucratic preferences is defined by the unique structural characteristics of the judiciary. In other words, while judges cannot do much to change the basic features of the separation of powers, judges can, and do, formulate the rules of procedure to give themselves greater control over their own agendas. The bureaucratic preferences of federal judges are informed by certain structural characteristics. In particular, federal judges (1) have broad jurisdiction over a wide variety of substantive areas of the law, (2) enjoy life tenure, (3) are paid salaries that may not be reduced in nominal terms, (4) must justify their decisions in the form of written opinions, and (5) are assigned cases at random and cannot advance their preferences by preselecting the kinds of cases that come before them. Moreover, judges' desire to control their own agendas is heightened by the fact that, for most judges, there is a considerable opportunity cost to serving on the judiciary because most judges could be earning more in private practice. ${ }^{9}$

In addition, judges inevitably will have made large, fixed human capital investments in the form of their knowledge of existing law. This human capital investment produces two sets of legal skills: one set is specific, and the other generic. As used here, a judge's specific skills consist of expertise in specialized areas of the law, such as securities regulation, admiralty, or criminal procedure. ${ }^{10} \mathrm{~A}$ judge's generic legal skills consist

\footnotetext{
${ }^{8}$ One judge has analyzed his profession "by treating judges as 'ordinary people' . . . domesticate[d] . . . for economic analysis." See Richard A. Posner, What Do Judges and Justices Maximize? (The Same Thing Everyone Else Does) 3 (Chicago L. and Econ. Working Paper No. 15, 2d Series, University of Chicago Law School, March 15, 1993).

${ }^{9}$ Even those judges who were not earning more than their judicial salaries at the time of their appointment could find higher-paying jobs in practice if they quit the bench and joined a firm because of the prestige associated with being a former judge. For a discussion, complete with formulas of the cost calculus involved in accepting a judgeship over private practice, see id. at 24-31.

10 Jonathan R. Macey, The Internal and External Costs and Benefits of Stare Decisis, 65 Chi. Kent L. Rev. 93, 95 (1989).
} 
of his expertise in areas of the law that are equally applicable across a wide range of cases. For example, the ability to conduct legal research is a generic legal skill; as is a detailed knowledge of the Rules of Evidence, or the Rules of Civil Procedure. Each of these structural features serves as a source for the distinct set of bureaucratic preferences that inform judges' selection of procedural rules.

On the basis of these simple observations about the nature of the judicial function, it is possible to develop three hypotheses about judicial preferences. First, because judges have lifetime tenure, they are less susceptible to the political pressures that affect the decisions of elected officials. ${ }^{11}$ This makes judges more likely to further their own self-interest by pursuing nonmonetary interests such as increasing leisure (reduction in workload), discretionary power to select which cases to consider, increased influence, and reputation within the legal community. ${ }^{12}$ This observation is consistent with Richard Posner's view that "judges, like other people, seek to maximize a utility function that includes both monetary and nonmonetary elements (the latter including leisure, prestige, and power)." 13 As applied to the Rules of Civil Procedure, we would expect judges to opt for those procedural rules that maximize their ability to make discretionary decisions and those rules that enable a judge to make such decisions quickly and with a minimum of outside interference. This flexibility allows judges not only to maximize leisure but also to reach legal results that maximize their own view of the good.

Second, judges' considerable human capital investment in the legal system is likely to align their preferences with the preferences (and interests) of the legal community as a whole. Consequently, judges are likely to view procedural rules that maximize the demand for lawyers' services as socially desirable, not because of any cynical desire to pad the pockets of members of the bar, but because of a tendency to see the benefits of procedural rules but not the costs. This tendency is a result of the fact that judges, like lawyers, internalize the benefits of procedural rules but externalize the costs on clients and on society generally.

Finally, judges will try to maximize their ability to utilize their generic legal skills. To the extent that procedural rules are generic rather than

\footnotetext{
${ }^{11}$ Posner, supra note 8, at 4: "Article III of the Constitution erects such a high hurdle to removing a federal judge from office that pretty much the only thing that will get him removed is criminal activity.'

${ }^{12}$ For a judge, leisure can translate into better judging and greater income to judges who pursue outside activities (depending on the type and extent of available moonlighting opportunities). Id. at 27-28.

${ }^{13}$ Posner, supra note 1, at 534. More recently, Posner has considered the "power" element as worth ignoring since it only affects a "small minority [of judges]." Posner, supra note 8 , at 3 .
} 
specialized, ceteris paribus, judges will attempt to maximize the range of cases that can be discharged through procedural devices.

\section{Procedural Rules and Judicial Preferences}

As noted above, a complete theory of how judicial preferences influence procedural rules must account for the structural features of the judiciary. In particular, federal judges are by and large judges of general jurisdiction. As such, a federal judge must decide cases involving a complex mix of state and federal laws, ranging from admiralty to bankruptcy to securities regulation. ${ }^{14}$ The task of judging has been made more difficult over time because of the rapid expansion in the number and complexity of federal statutes. ${ }^{15}$ The explosion in statute making has made it impossible for federal judges to master the substantive rules of law in all of the fields of law in which they must generate legal opinions. Procedural rules can serve the self-interest of judges by permitting them to use procedural grounds as a basis for deciding cases, thereby avoiding the necessity of acquiring detailed specialized knowledge of substantive areas of law.

The theory developed here has an empirical component because one would predict that an individual judge will be more likely to dispose of a case on procedural or technical grounds where he lacks particularly strong views or unique expertise in the substantive area of law at issue. A judge who has invested considerable human capital in learning the substantive law of securities regulation (because, for example, that was his specialty in practice before becoming a judge) is less likely to dispose of a case involving securities law issues on technical, procedural grounds. Similarly, a judge with no expertise in admiralty will be more likely to dispose of cases involving admiralty issues on procedural grounds than those who have such expertise.

Thus, from the judges' perspective, procedural rules permit judges to dispose of unwanted cases yet still allow them to utilize their substantive knowledge in those areas in which they have particular expertise or interest. This analysis is consistent with Frederick Schauer's observation that the plain meaning rule is most often invoked when judges are called on to decide cases involving what many perceive as uninteresting, highly technical areas of the law such as the Employment Retirement Income Security Act, social security, and taxation. Substantive legal reasoning,

14 See Jonathan R. Macey \& Geoffrey P. Miller, The Canons of Statutory Construction and Judicial Preferences, 45 Vand. L. Rev. 647, 660 (1992).

${ }^{15}$ For descriptions of the magnitude and nature of the explosion in statute making at the federal level, see Henry J. Friendly, Federal Jurisdiction: A General View 4 (1973); Guido Calabresi, A Common Law For the Age of Statutes (1982). 
however, is invoked by judges to decide more interesting cases involving such issues as flag burning, affirmative action, separation of powers, or patronage. ${ }^{16}$

Seen in this way, the rules of procedure serve as a substitute for other generic legal rules, such as the canons of statutory construction or the rule of stare decisis. All of these rules can be viewed as vehicles by which judges can decide cases using generic legal rules that do not require knowledge of the substantive legal issues involved in the underlying dispute.

\section{A. Dismissal}

The most obvious way for a trial judge to invoke the rules of procedure to dispose of a case that he does not wish to decide on the merits is by simply dismissing the case as a matter of law for failure to state a claim. For a variety of reasons, this is unlikely to be a very effective strategy for trial judges seeking to maximize narrow self-interest. First, the fact that one judge finds the legal issues in a particular case uninteresting does not mean that other judges-including appellate judges-will find them uninteresting. The rulings of federal trial judges are subject to review by appellate panels of three judges. The availability of three-judge panels of review makes it three times as likely that one of the appeals judges reviewing the case will find the substantive issue involved to be interesting. This means that the probability of reversal for simple dismissals is likely to be considered intolerably high for a trial judge. Judges will care about reversal in this context for two reasons. First, judges have an interest in avoiding being reversed because of the adverse reputational effect of a reversal. ${ }^{17}$ In addition, when a case is reversed on appeal it generally is returned to the trial judge who originally ordered the dismissal. Consequently, dismissal on the law, if reversed, will not permit the trial judge to avoid hearing the case.

An additional reason why procedural rules are not likely to be used to discharge cases on the law is that lawyers involved in drafting procedural rules have a strong monetary interest in avoiding early dismissal. For this reason, even "trivial or incremental" alterations in the procedural rules that reduce the demand for lawyers' services are likely to "encounter enormous resistance." 18

${ }^{16}$ Frederick Schauer, Statutory Construction and the Coordinating Function of Plain Meaning, 1990 S. Ct. Rev. 231, 247.

17 Posner, supra note 1, at 534.

${ }^{18}$ Winter, supra note 5, at 263. 


\section{B. Settlement}

Most important, dismissing cases on the law is likely to be a rare occurrence because trial judges have a superior, low-cost alternative to such dismissals: forcing settlements. Forcing settlements is superior to dismissing cases from the judiciary's perspective because it drastically reduces the probability of reversal. Forcing settlements is also superior to dismissing cases from the perspective of the legal community. As Geoffrey Miller has observed, because attorneys will have superior information about the prospects for success for a case than their clients, the power over the settlement decision generally will be shared by the lawyer and the client. Lawyers can be expected to shade their legal advice regarding settlement to suit their own interests. ${ }^{19}$ Knowing this, judges can buy the cooperation of the legal community in their efforts to obtain settlements by conducting settlement negotiations in such a way that it is in the economic interests of lawyers to encourage their clients to settle.

Interestingly, while judges who dismiss cases on the law risk tarnishing their reputations, judges actually can enhance their reputations by devising "innovative" or "creative" settlements. For example, Rule 16 of the Federal Rules of Civil Procedure permits a trial judge to direct the attorneys for the parties to appear at a pretrial conference for the purpose of "facilitating the settlement of the case." ${ }^{20}$ But judges can invoke Rule 16 simply to rid a case of what they regard as frivolous or uninteresting issues of fact and law, whether or not requested by one of the parties. ${ }^{21}$ Moreover, the Advisory Committee on Rules of Practice and Procedure would have amended Rule 16 to authorize courts to require not only lawyers but also the parties or their insurers or both to attend settlement conferences and to participate in alternative dispute resolution procedures designed to foster settlement. Lawyers objected to this proposal, claiming that "explicit authority to require party attendance at settlement conferences would be misused by judges to coerce settlements." 22 Consistent with Miller's analysis of the agency problems involved in settlement, it is notable that the lawyers did not object to judges coercing

19 See Geoffrey P. Miller, Some Agency Problems in Settlement, 16 J. Legal Stud. 189, 214 (1987).

${ }^{20}$ F.R.C.P. 16(a)(5).

21 F.R.C.P. 16(c)(1) provides for pretrial conferences to include "the formulation and simplification of the issues, including the elimination of frivolous claims or defenses." The Advisory Committee Notes (1983) say this rule "confirm[s] the court's power to identify ... the real issues prior to trial, thereby saving time and expense for everyone."

22 Sam C. Pointer, Jr., Chairman, Advisory Committee on Civil Rules, Letter to Hon. Robert E. Keeton, Chairman, Standing Committee on Rules of Practice and Procedure, May 1, 1992, Attachment B, page 6. 
settlements without the clients being present. They only objected to having clients present to observe the discussions of the division of gains from settlement. Put another way, if there were no agency costs in the attorney-client relationship, there would be no reason for lawyers to object to settlement discussions at which the clients would appear. As a compromise between the judicial interests in coercing settlements and the bar's interests in controlling settlement negotiations, it was agreed that party representatives would be made accessible by telephone during settlement negotiations with the court. Moreover, the proposed amendments to Rule 16 do not deter judges from exercising their inherent powers to compel parties to attend pretrial conferences or to participate in alternative dispute resolution procedures.

\section{Rule 68: Discovery and Automatic Disclosure}

As noted above, judges are likely to use the rules of procedure to increase their control over litigation. Judges control litigation by retaining the power to dispose of unwanted cases by coercing settlements and by expanding their ability to dismiss cases without reference to the underlying substantive legal issues. In addition, building on the assumption that judges care about prestige and prefer important cases to trivial cases, we can expect procedural rules designed to raise the fixed costs of litigation in order to weed out small cases.

Under Rule 68, for example, a plaintiff who refuses a settlement offer, goes to trial, and obtains a judgment that is less favorable than the defending party's offer must pay all of the defendant's postoffer costs. Such a rule is best viewed as a mechanism for reducing the incidence of smallstakes litigation, rather than as a mechanism for encouraging settlement. As Miller has observed, the popular justification for Rule 68, namely that the rule encourages settlements, is fallacious because it ignores the fact that defendants faced with Rule 68 simply will lower their settlement offers to plaintiffs. ${ }^{23}$ This, in turn, will not so much encourage settlement as drive down the level of settlement offers.

The costs that courts may assess against plaintiffs choosing not to accept an offer of settlement under Rule 68 generally do not include attorneys' fees, but only fixed costs such as filing fees and the cost of deposition transcripts. ${ }^{24}$ Consequently, the real effect of Rule 68 is to lower the expected value of cases to plaintiffs by raising the expected

\footnotetext{
${ }^{23}$ Miller, supra note 6, at 94.

${ }^{24}$ This general rule does not apply where the applicable substantive statute includes attorneys' fees as part of costs. Marek v. Chesny, 473 U.S. 1, 9 (1985).
} 
costs. But because the costs affected by Rule 68 are fixed costs, plaintiffs' incentives to bring small cases will be affected disproportionately. Thus Rule 68 not only shifts wealth from plaintiffs to defendants, it also increases the utility of certain judges because lawyers will not be able to justify bringing a case with Rule 68 in place that they might bring without it. This reduced volume of cases will provide judges more leisure time and a docket of more significant cases. Cases that might be brought in the absence of Rule 68 will not be brought with the rule in place.

Recent analysis of Rule 68 reinforces the argument that the peculiar design of this rule can best be explained as a mechanism for maximizing judicial utility, rather than for maximizing the efficiency of the legal system. In a recent study, Kathryn Spier has shown that Rule 68 will tend to increase the likelihood of settlement where the litigants disagree about damages but agree about liability. In constrast, when the litigants disagree about liability, but agree about damages, Rule 68 will tend to decrease the likelihood of settlement. This corresponds with the basic intuition that lawyers and judges will find liability (that is, legal) issues more interesting than damages issues, which generally revolve around such nonlegal issues as the plaintiff's expected future earnings. ${ }^{25}$

The above arguments about Rule 68 apply with even greater force to the liberal rules for discovery. Under modern discovery rules, litigants can select whatever discovery tools they wish-interrogatories, depositions, document requests-and can conduct free-form investigations of their opponents' records without regard for the particularities of the pleadings or the precise nature of their positions. ${ }^{26}$ The liberal rules of pretrial discovery involve "considerable to enormous waste." 27 In particular, "a no-stone-left-unturned (sometimes a no-grain-of-sand-leftunturned) philosophy of discovery governs much litigation and imposes costs, usually without corresponding benefits. Costly discovery undertaken with only a marginal effect on the outcome of litigation constitutes an economic loss to society. Like any wasteful practice, it uses up resources that could be put to more productive uses." 28

${ }^{25}$ Kathryn E. Spier, Pretrial Bargaining and the Design of Fee-shifting Rules, 25 RAND J. Econ. (1994, in press).

${ }^{26}$ Jeffrey J. Mayer, Prescribing Cooperation: The Mandatory Pretrial Disclosure Requirement of Proposed Rules 26 and 37 of the Federal Rules of Civil Procedure, 12 Rev. Litigation 77,85 (1992).

27 Winter, supra note 5 , at 263.

${ }^{28}$ Id. at 264. As Deborah Rhode has observed, lawyers engage in a great deal of discovery. In her words, lawyers leave "no stone unturned, provided, of course, they can charge by the stone." See Rhode, Ethical Perspectives on Legal Practice, 37 Stan. L. Rev. 589, 635 (1985). 
Perhaps the most common explanation for the survival of the patently inefficient rules of discovery is that they benefit lawyers at the expense of clients. Litigants become the victims of their lawyers' self-interest. The argument is that lawyers profit from more discovery because often they are paid by the hour and thus benefit both from more discovery as well as more litigation about discovery. ${ }^{29}$ While this analysis has some explanatory power, it is not a complete explanation of the existence of liberal discovery because it ignores the fact that there are costs as well as benefits to lawyers from such rules. In particular, from the lawyers' perspective, liberal discovery rules increase the fees garnered in individual cases, but they decrease the overall demand for legal services by driving up the price of such services. Thus, plaintiffs' lawyers will be less able to convince prospective clients to file lawsuits because such clients will be aware of the enormous cost of discovery. Even those who explain liberal discovery rules on the basis of the divergence of interest between lawyers and clients acknowledge that "discovery is sometimes used as a club against the other party. Unlimited discovery allows a party to impose costs on an adversary solely to increase the adversary's expenses. The anticipation that bringing or defending a lawsuit will be costly, regardless of the merits, may cause a party with a meritorious claim or defense not to sue, to give up early, or to settle for an amount less than defense costs." 30

Similarly, one would predict that market forces would emerge to mitigate the agency cost problems that exist between lawyers and their clients. And they have. In recent years corporate inside counsel has become more active in monitoring outside legal services. An entire cottage industry of consulting firms who specialize in auditing legal bills has emerged as well. ${ }^{31}$ These developments can be expected to reduce lawyers' demand for open-ended discovery, and one would predict that these developments would lead lawyers to respond by voluntarily reducing the costliness of discovery.

Thus, it is hard to conclude that a rule that raises the marginal costs of bringing lawsuits unambiguously benefits lawyers. It is clear, however, that such rules benefit judges in two ways. First, the liberal rules of discovery reduce total litigation, thereby reducing judges' overall caseloads. Second, liberal discovery rules constitute fixed costs for bringing litigation because there is no legal rule that reduces strategic behavior by

29 Winter, supra note 5, at 277 .

${ }^{30}$ Id. at 277.

${ }^{31}$ David P. Land, Reasonableness and Auditing Legal Fees, N.Y. L. J., February 25, 1993 , at 5. 
lawyers by limiting the extent of the discovery available in small stakes litigation..$^{32}$ Consequently, the liberal rules of discovery may have a disproportionate impact on small stakes litigation because discovery will constitute a higher percentage of the total expected recovery in such litigation.

Of course, the parties requesting discovery bear some of the costs associated with their discovery requests. We would therefore expect less discovery in small stakes litigation because clients will only be willing to incur litigation costs up to the amount of any expected recovery. Cases with small expected recoveries will not justify elaborate discovery requests. Consistent with this analysis, a study by the Federal Judicial Center showed that recovery requests were recorded with the district court in fewer than one-half of the 3,114 cases studied. In the majority of cases there were no discovery requests at all. ${ }^{33}$ Other studies show that in 95 percent of cases, there are fewer than five discovery requests made. ${ }^{34}$ Nonetheless, abuse of the discovery process is well documented, and it can be used to coerce settlements and to reduce the incidence of litigation, particularly small stakes litigation. ${ }^{35}$ However, given the rather limited use of discovery in small stakes litigation, self-interested judges might try to develop another mechanism for reducing the percentage of their caseloads composed of such litigation.

The Advisory Committee on the Federal Rules of Civil Procedure recently recommended that courts be permitted to limit discovery where "the burden or expense of the proposed discovery rule outweighs its likely benefit, taking into account the needs of the case, the amount in controversy, the parties' resources, and the importance of the proposed discovery in resolving issues." 36 This new rule does not alter the existing equilibrium at all. Under the current rules, judges can limit discovery where such discovery will be unduly burdensome. ${ }^{37}$ As before, under the

${ }^{32}$ F.R.C.P. 26(b)(1)(iii) does, however, permit a judge to limit discovery where it will be "unduly burdensome or expensive, taking into account the needs of the case, the amount in controversy, limitations on the parties' resources, and the importance of the issues at stake in the litigation." Of course, a judge is free to decline to invoke this rule when he wants to coerce a settlement.

${ }^{33}$ David M. Trubek et al., The Costs of Ordinary Litigation, 31 UCLA L. Rev. 72, 90 (1983).

34 Paul R. Connolly, Edith A. Holleman, \& Michael J. Kuhlman, Judicial Controls and the Civil Litigative Process: Discovery (1978).

${ }^{35}$ Winter, supra note 5 (discussing how discovery can be used as a "club" to coerce settlements).

${ }^{36}$ Proposed F.R.C.P. 26(b)(2)(iii). Proposed Amendments to the Federal Rules of Civil Procedure and the Federal Rules of Evidence, Submitted to Standing Committee on Rules of Practice and Procedure By Advisory Committee on Civil Rules, May, 1992.

${ }^{37}$ See note 32 supra. 
proposed rule, judges benefit because they can control discovery. Judges can permit broad discovery when they want to raise litigation costs and encourage early settlement. At the same time, lawyers can increase the supply of litigation by making a credible claim to clients that litigation costs can be reduced by limiting discovery.

More important, a proposed amendment to Rule 26 would require in every case automatic disclosure of certain core information including the names and addresses of witnesses and the location and categories of documents "relevant to disputed facts alleged with particularity in the pleadings." 38 Critics of the proposed rule within the legal community argued that it would produce more confusion, delay, and expense than existing discovery rules because attorneys would be free to manipulate the standard without fear of penalty. ${ }^{39}$ The legal community also argued that the rule would assist plaintiffs by requiring defense counsel to respond to every legal theory that might support the plaintiff's complaint, including theories the plaintiffs had not considered. ${ }^{40}$

This proposed rule would reduce judicial workloads by reducing the incentives of lawyers to bring small stakes litigation in two ways. First, small stakes cases would be deterred because the rule would impose yet another fixed cost on the litigation process. Second, and more important, this proposed rule would require document production in every case, including the 50 percent of cases in which there was no document production at all prior to the implementation of the rule. As such, the proposed amendment to Rule 26 will have a disproportionate effect on small stakes litigation by requiring the production of documents that would not have been produced in the absence of such a rule. ${ }^{41}$ Ironically, a set of rule changes ostensibly designed to streamline the discovery process will result in even more document production than before. It is not surprising that many practitioners believe that the proposals for discovery reform reflect an outcome in which lawyers' interests are being "sacrificed to the judicial agenda [of reducing the workload of the courts] without any airing of the issues." ${ }^{42}$

\section{Chevron v. Natural Resources Defense Council}

Perhaps the most striking example of the judiciary's efforts to claim control of their own agendas is reflected in Chevron U.S.A, Inc. v. Natu-

\footnotetext{
38 Proposed F.R.C.P. 26(a).

${ }^{39}$ Mayer, supra note 26, at 113.

40 Winter, supra note 5 , at 267.

${ }^{41}$ I am grateful to my colleague Kevin Clermont for this point.

42 Laura A. Kaster \& Kenneth A. Wittenberg, Rulemakers Should Be Litigators, Nat'1 L. J., August 17, 1992, at 15.
} 
ral Resources Defense Council, Inc. ${ }^{43}$ Chevron involved the Environmental Protection Agency's (EPA) "bubble" policy, which contained a new way to measure discharges of industrial pollution controlled by the Clean Air Act. The EPA's new policy gave the agency the discretion to define the statutory term "stationary source" to mean either any polluting device within a plant or an entire manufacturing plant. In some states this interpretation had the effect of reducing manufacturers' costs of complying with the Clean Air Act.

At issue in Chevron was whether the EPA's new definition of "stationary source" violated the Clean Air Act. But the opinion contained sweeping language on the need for courts to defer to administrative agency interpretations of ambiguous statutes, including statutes on subjects far removed from the Clean Air Act. In what has been described as one of the "defining cases in the last twenty years of American public law," the Court held that an administrative agency's construction of a statute would be upheld unless it is unreasonable or otherwise impermissible. ${ }^{45}$ This case has been severely criticized as "a striking abdication of judicial responsibility" and "quite incompatible with Marshall's aphorism that '[i]t is emphatically the province of the judicial department to say what the law is." "46 The criticism of Chevron is based on the fact that the decision creates enormous possibilities for judicial abdication to agency decisions.

From the perspective of the self-interest of the judiciary, however, Chevron must be viewed as an act of genius. The opinion increases dramatically the ability of judges to control their own agendas. As the Court in Chevron made clear, courts may draw on "traditional tools of [statutory] construction" when evaluating agency interpretations of statutes. In this respect, judges may defer to agencies when they want to. Alternatively, whenever a judge thinks that an agency's interpretation of a statute contradicts the plain meaning of the law, the overall structure of a statutory scheme, the relevant legislative history, or even the underlying purposes of a statute, he is free to ignore Chevron's call for deference and overrule the agency. ${ }^{47}$

${ }^{43}$ Chevron U.S.A., Inc. v. Natural Resources Defense Council, Inc., 467 U.S. 837 (1984).

44 Cass R. Sunstein, Law and Administration after Chevron, 90 Colum. L. Rev. 2071, 2075 (1990).

45 Chevron, 467 U.S. 837, at 843-845.

46 Antonin Scalia, Judicial Deference to Administrative Interpretations of Law, 1989 Duke L. J. 511, 513-14 (quoting Marbury v. Madison, 5 U.S. (1 Cranch) 137, 177 (1803)).

47 Jonathan R. Macey, Separated Powers and Positive Political Theory: The Tug of War - over Administrative Agencies, 80 Georgetown L. J. 671, 681 (1992). 
The decision in Chevron allows federal judges to invoke a generic procedural value-deference to the expertise of administrative agencieswhenever they wish to avoid considering the merits of an agency ruling. In constrast, the ruling in Chevron is sufficiently flexible that judges who have developed a specialty in a particular area, or have strong preferences about the outcome of a particular case, are completely free to ignore the agency's interpretation. ${ }^{48}$ Thus the Court's ruling in Chevron allows judges simultaneously to take full advantage of any specific human capital investments they have made in learning particular areas of the law and to decide other cases on the basis of generic legal skills. No judge will have the expertise, or the inclination, to handle all of the areas of substantive law that come before him.

Similarly, Chevron also serves the interests of judges who want to minimize the time and effort involved in judging. After Chevron one would expect that those judges with particularly strong tastes for leisure would invoke the Chevron invitation simply to defer to agency expertise. Those judges, however, with more ambition, or conviction, or with a stronger agenda are free to ignore the determinations of administrative agencies when they so choose.

\section{Procedural Rules, Judicial Preferences, and the Public Interest}

Although the theory developed in this article is based on judicial selfinterest, the theory is descriptive rather than normative. Nothing in the theory would suggest that judges acting in their own self-interest will craft rules that are systematically inefficient.

By contrast, over a wide range of issues, the judiciary's influence on the development of procedural rules will move such rules in the direction of clients' and society's interest by offsetting the influence that lawyers have on the development of the law. For example, as noted above, judges' ability to streamline the discovery process will mitigate the agency-cost problem that exists between lawyers and their clients. Similarly, judges' power to force settlements on lawyers will benefit some clients by reducing the ability of lawyers to prolong litigation in order to amass more billable hours.

As well, the use of procedural rules to discharge cases on the basis of generic legal skills may be efficient because it reduces the cost to judges of specializing in certain areas of law. Because judges can dispose of a wide range of cases on the basis of generic legal skills, the opportunity

${ }^{48}$ Sunstein, supra note 44 , at 2092 (whenever a court "has a firm conviction that the agency interpretation violates the statute, that interpretation must fail"). 
cost of specializing in one area of the law is reduced. Thus, even judges of general jurisdiction can retain their specialties in particular areas of the law by disposing of cases in areas they know nothing about by forcing settlements or by invoking a decision rule such as one of the canons of statutory construction, or the rule of stare decisis, or some other procedural device that involves the application of a generic legal skill.

It would be wrong to view the impact of judicial self-interest on procedural rules as providing only benefits and no costs. The preceding analysis suggests that judicial self-interest causes some inefficiencies in the litigation process. For example, it appears likely that judges' tastes for leisure cause them to raise the costs of litigation above the socially optimal level. Rule 68 of the Federal Rules of Civil Procedure, along with the high fixed costs of discovery rules, move the threshold point at which the expected benefits of bringing a lawsuit are outweighed by the costs, particularly for small stakes claims, to inefficient levels. Similarly, litigation produces a public good in the form of legal precedent. Legal precedents are of general social value because they lower the transaction costs of doing business. Judges' self-interest leads them to craft procedural rules that reduce the percentage of cases ultimately resolved on the merits. Because more cases are resolved on technical, procedural grounds, the available supply of precedents is adversely affected by judicial selfinterest.

Finally, to the extent that the procedural rules allow judges to obtain settlements in cases that would not otherwise be settled and to discharge cases on purely procedural grounds, the risk that judges will decide cases willfully (that is, on the basis of their own narrow preferences without regard to efficiency norms, or precedent, or other neutral principles) goes up. This is because when a judge is able to coerce a settlement or to discharge a case from his docket on purely procedural grounds, he avoids the general requirement that judges justify their decisions on the basis of a formal, written opinion.

The nature of judicial preferences also can help explain why judges have not gone further in pressing for changes that would reduce caseload growth. Perhaps the best-known suggestion for dealing with the explosion in judges caseloads is the proposal to establish a new federal appellate court that would serve as a buffer between the courts of appeal and the Supreme Court. As Posner has pointed out, the creation of intermediate appellate courts, by making the judicial system more hierarchical, would respond effectively to caseload growth. ${ }^{49}$ In fact it was the problem of

\footnotetext{
${ }^{49}$ Posner, supra note 1 , at 580.
} 
caseload growth that led most states, as well as the federal authorities, to create an intermediate appellate court between the trial court and the supreme court. ${ }^{50}$ However, the creation of such a court would benefit the Supreme Court at the expense of the federal appellate courts, by reducing the caseload of the Supreme Court and the prestige of the lower federal courts of appeal. For this reason, the proposal to create a new appellate court just below the Supreme Court has been vigorously opposed by appellate court judges.

Similarly, it is interesting that Congress has responded to the federal courts' caseload problem, not by imposing higher filing fees, but instead by setting and raising minimum threshold levels for bringing lawsuits. The efficient solution to the caseload problem would be to impose filing fees. ${ }^{51} \mathrm{~A}$ minimum amount in controversy requirement is the equivalent to setting an infinite fee for cases below the minimum and a zero fee for cases above the level. However, no one actually collects such a fee. By contrast, a fixed fee imposes what is, in effect, a proportionally declining tax on lawsuits, thereby causing litigants to internalize the costs of using the court system. ${ }^{52}$ The minimum amount in controversy requirement used in the federal court system is inefficient compared to a filing fee system because the requirement subsidizes litigation. If a case meets the minimum requirements, the litigants do not have to contribute to the costs of the judicial system. ${ }^{53}$ However, judges are likely to prefer a minimum amount in controversy requirement because such requirements operate as a fixed cost on litigation, ensuring that small claims disfavored by judges will not be brought.

\section{Turning Substantive Rules into Procedural Rules: LESSONS FROM CORPORATE LAW}

Judges will tend to decide cases in ways that allow them to take advantage of their own skills and expertise. For example, while judges generally have little, if any, expertise in statistics or economics or finance, they have significant expertise in existing procedural norms. Consequently, while a judge is unlikely to be able to evaluate the substantive terms of a particular transaction, or to determine whether a particular price is fair, he will be able to evaluate whether a preexisting set of procedural rules have been followed by litigants. Judges who wish to expedite the disposi-

\footnotetext{
so Id.

${ }^{51}$ Id. at 581 .

52 Id.

${ }^{53}$ Id.
} 
tion of cases will replace substantive law analysis with procedural rules. ${ }^{54}$ Judges will not only invoke procedural rules to dismiss cases, they also will transform substantive rules of law into procedural rules. Thus, judges are likely to establish substantive legal rules that are, in effect, procedural.

For example, in Smith v. W. Van Gorkom ${ }^{55}$ the shareholders of Trans Union Corporation filed a class-action lawsuit against the firm's board of directors, seeking to set aside a merger between Trans Union and a wholly owned subsidiary of Marmon Group, Incorporated. This merger allowed the plaintiffs to realize a profit of more than 50 percent on the premerger price of their stock. The Delaware supreme court decided that the Trans Union directors had acted in a grossly negligent manner in approving the merger proposal because they had not developed an adequate procedural framework for analyzing the proposal.

What is remarkable about the opinion is that despite the imposition of draconian damages on the individual directors who were defendants, the remedy prescribed was "purely a nostrum" 56 because "corporate managers faced with a situation like that confronting the Trans Union board can insure against liability by demonstrating that the board has engaged in due deliberations." 57 In other words, corporate directors can engage in virtually any transaction they wish, without fear of challenge, simply by creating the procedural appearance of fairness. Lawyers create the appearance of fairness by ensuring that the corporate minutes reflect lengthy and thorough discussions of the proposed transactions and by providing the decision makers with all relevant documents. Of course, these procedures, while costly, "do not provide any reliable guarantee that the transaction will benefit shareholders." do accomplish is to allow judges to focus their decision making on issues with which they are comfortable.

Commentators have observed that these sorts of rules amount to a tax on corporate control transactions. This tax benefits both lawyers and judges. It benefits lawyers by increasing the demand for their services, and it benefits judges by allowing them to substitute a generalized judicial inquiry into the procedures used in a particular transaction, for the difficult and fact-intensive analysis that otherwise would be required.

Perhaps the best example of the judiciary's efforts to substitute proce52.

${ }^{54}$ Stephen Reinhardt, Too Few Judges, Too Many Cases, A.B.A. J., January 1993, at

55 Smith v. W. Van Gorkom, 488 A.2d at 858 (Del. 1985).

${ }^{56}$ Macey and Miller, Trans Union Reconsidered, 98 Yale L. J. 127, 134 (1988).

${ }^{57}$ Id.

${ }^{58}$ Id. 
dural rules for substantive rules of law lies in the corporate law rules regarding valuation issues. Despite the fact that sophisticated techniques of corporate finance have made valuation much more objective than ever before, courts consistently have emphasized that procedural rules are more important than substantive legal rules. For example, in Weinberger v. UOP, Inc., ${ }^{59}$ the Delaware supreme court decided that the procedures followed by a board of directors in evaluating the price paid by a majority shareholder for a corporation under its control was insufficient, even when the shares of the corporation being purchased were publicly traded and the price paid represented a 50 percent premium over the market price of the subsidiary's shares. Weinberger involved the purchase by Signal Corporation of shares in UOP, whose stock was traded on the New York Stock Exchange. Signal, which owned 50.5 percent of UOP's stock, wanted to increase its ownership to 100 percent. In evaluating the fairness of the transaction, the court made it clear that the preoffer market price of UOP was of less importance than the procedures established by Signal for arriving at the price. ${ }^{60}$ The rule established in Weinberger has resulted in a new set of procedures in cash-out merger transactions that increase the cost of consummating such transactions, without any apparent benefit to the minority shareholders. The result in Weinberger can best be explained as an effort to transform substantive legal issues that judges find difficult to master into procedural rules that are easy for judges to administer.

Indeed, under existing corporate law, virtually any transaction can be insulated from legal challenge if a sufficient procedural framework is established and followed. It is impossible to justify the systematic "proceduralization" of substantive corporate law rules without taking account of the judges' preference for procedural over substantive rules.

\section{Conclusion}

Judges sometimes are heard to complain about their ever-increasing caseloads. ${ }^{61}$ The preceding analysis demonstrates that, while such complaints may be useful in allowing judges to extract more resources from Congress, ${ }^{62}$ these complaints may be exaggerated, particularly given that

59457 A.2d 701 (1983).

${ }^{60}$ Weinberger v. UOP Inc., 457 A2d, at 708-12.

${ }^{61}$ Richard A. Posner, The Federal Courts: Crisis and Reform, 65, 80 (1985); Reinhardt, supra note 54 , at 52 .

62 On average, each new federal judgeship is estimated to cost more than $\$ 1$ million annually for salaries, staff, and other expenses. See Stephen A. Labaton, Clinton May Use Diversity Pledge to Remake Courts, N.Y. Times, March 8, 1993, at A1, B9. 
elected officials have strong incentives to expand the number of federal judgeships. ${ }^{63}$

Judges have considerable ability to control their own agendas by crafting decision rules that allow judges to dispose of cases quickly and cheaply. These rules also enable judges to winnow out undesirable, small stakes litigation and to devote more energy to cases in which they are interested and less energy to cases that are of little entertainment value. Of course, judges have not captured the rule-making process completely. Lawyers and other interest groups, such as court reporters, insurance companies, and other large consumers of judicial services, inevitably influence the process. But as the above discussion has shown, the ability of the federal judiciary to control the process by which the Federal Rules of Civil Procedure are revised gives them a distinct advantage over competing interest groups in obtaining procedural rules that reflect their own bureaucratic self-interest.

${ }^{63}$ Moreover, the president and Congress have incentives to create more federal judgeships in order to provide "more ways for senators [and presidents] to reward loyal supporters," while simultaneously claiming to devote more resources to fighting crime. See id. at B9. 